\title{
New records of Castor canadensis from the Conchos River, Chihuahua, México
}

\section{Nuevos registros de Castor canadensis en el Río Conchos, Chihuahua, México}

Juan Pablo Gallo-Reynoso ${ }^{*}$, Isai David Barba-Acuña ${ }^{1}$, Verónica Farías-González² ${ }^{2}$ Samuel Macías-Sánchez ${ }^{3}$, Lucila Armenta-Méndez', Gloria Ponce-García ${ }^{1}$, Jimena J. Guerrero-Flores ${ }^{4}$, Juan Guillermo A. Brito-Rios ${ }^{5}$, Tania Elizabeth Quintana-Salvador ${ }^{1}$, and Alicia A. Ortega-Padilla ${ }^{6}$

${ }^{1}$ Centro de Investigación en Alimentación y Desarrollo, A. C. Unidad Guaymas. Carretera al Varadero Nacional km 6.6, Col. Las Playitas, C. P. 85450. Guaymas, Sonora, México. E-mail: jpgallo@ciad.mx (JPG-R), isai.barba@ciad.mx (IDB-A), lucila.armenta@ gmail.com (LA-M), gloria.ponce.garcia@gmail.com (GP-G), elisaalvador@hotmail.com (TEQ-S).

${ }^{2}$ Laboratorio de Recursos Naturales, Unidad de Biología, Tecnología y Prototipos, Facultad de Estudios Superiores Iztacala, UNAM. Av. de los Barrios 1. Col. Los Reyes Iztacala, C. P. 54090. Tlalnepantla de Baz, Estado de México, México. E-mail: v.farias@unam. $\mathrm{mx}(\mathrm{VF}-\mathrm{G})$.

${ }^{3}$ Instituto de Biotecnología y Ecología Aplicada, Universidad Veracruzana. Avenida de las Culturas Universitarias No. 101, Col. Emiliano Zapata, C. P. 91090. Xalapa de Enríquez, Veracruz, México. E-mail: macsanch@yahoo.com (SM-S).

${ }^{4}$ Calle Prolongación 5 de Mayo 936. Col. Valle Don Camilo, C. P. 50140. Toluca, Estado de México, México. E-mail: jimenag.sci@ gmail.com (JJG-R).

${ }^{5}$ Universidad de Guadalajara, Centro Universitario de la Costa Sur, C. P. 48900. Autlán de Navarro, Jalisco, México. E-mail: guillermo challenger@hotmail.com (JGAB-R).

${ }^{6}$ Calle 64, No. 437, Parque Santa Lucia, Centro, C. P. 97000. Mérida, Yucatán, México. E-mail: alicia.ortega@yucatan.gob.mx (AAO-P).

*Corresponding author

The North American beaver (Castor canadensis), has not been recorded in Chihuahua since 1972. We surveyed several sections of the Conchos River and its affluents in different areas of Chihuahua by walking along the rivers or canoeing looking for signs of their presence (tracks, gnawed tree trunks, felled trees and dens), in areas were beavers have been recorded in the past. We found no beavers in the surveyed areas of the Conchos River and its tributaries. The only place at Conchos River that we found them was at Pegüis Canyon. The area is the only weII-preserved habitat where beavers were found. This beaver population is probably derived from the beavers found at Río Grande near Ojinaga or from the Natural Protected Area of Cañón de Santa Elena further south. Our findings suggest that the area is fairly well-preserved and important for the distribution of beavers in northern México. There is a clear need to conserve this section of the Conchos River as an important corridor for beavers, which are listed as endangered by NOM-059-SEMARNAT-2010.

Key words: Aquatic mammal; beaver; biodiversity; conservation; Pegüis Canyon; riparian habitat.

El castor (Castor canadensis), no ha sido registrado en el Estado de Chihuahua desde 1972. Monitoreamos varias secciones del Río Conchos y sus afluentes en diferentes localidades de Chihuahua, caminando por las orillas del río o usando canoas, buscando indicios de su presencia (huellas, troncos roídos o derribados y madrigueras), en donde los castores habían sido registrados con anterioridad. No se encontraron castores en las áreas monitoreadas del Río Conchos y sus tributarios. El único sitio en este río en donde los encontramos fue en el Cañón del Pegüis. Esta localidad es el único hábitat bien preservado para los castores. Esta población de castores probablemente se deriva de los castores del Río Grande cerca de Ojinaga o de los castores del Área Natural Protegida Cañón de Santa Elena más al sur. Nuestros hallazgos sugieren que el área se encuentra bien conservada y que es importante para la distribución de los castores en el norte de México. Existe una clara necesidad de conservar esta sección del Río Conchos como un importante corredor para los castores, cuya especie se encuentra protegida, listada como en peligro de extinción por la NOM-059-SEMARNAT-2010.

Palabras clave: Biodiversidad; castor; conservación; Cañón del Pegüis; hábitat ripario; mamífero acuático.

@ 2020 Asociación Mexicana de Mastozoología, www.mastozoologiamexicana.org

Beavers have a northern distribution in México, they mainly inhabit the basins of rivers flowing northwestward, northward, or northeastward in the Río Bravo (Río Grande), or southward in the Colorado River (Leopold 1959). In the State of Sonora, beavers inhabit the Bavispe River basin, which flows westward from the Sierra Madre Occidental in western Chihuahua (Gallo-Reynoso et al. 2002; Caire 2019) and its tributary, the Cajón Bonito River, which flows southward from the Sierra San Luis mountain range (GalloReynoso pers. obs.; Pelz-Serrano et al. 2005). On the other hand, beavers also live in the San Pedro River (a tributary of the Gila River, Arizona), which flows in a northwest-north direction and joins the Colorado River in western Arizona (Olivares-Rivera 2018). Beavers were extirpated from the Sonora River in the early twentieth century when copper mines started operations in the Cananea region, and the river waters were heavily used along with extensive logging to feed water vapor for the machinery used in mills and for smelting copper ore (Mearns 1907; Villa-Ramírez 1954; Caire 2019). 
Beavers extended the southern end of their range into México during the Miocene and Pliocene (Rybczynski et al. 2010). The current extensive vicariant distribution range of beavers in México probably dates back to the last glacial period ( 20,000 to 12,000 years before present) that reached the northern border of México (states of Tamaulipas, Nuevo León, Coahuila, Chihuahua, Durango, Sonora, and Baja California), driving the distribution of beavers southward. Then, the range of beavers retracted northward following the melting and redistribution of ice during the Pleistocene glaciation events (Rybczynski et al. 2010). Whole riparian ecosystems that had dominated the landscape during the glacial period also moved north. This riparian ecosystem gave rise to extensive biogeographic barriers such as the Chihuahuan and Sonoran deserts, and the subtropical temperate areas found in Texas and Tamaulipas plains. The basins of the rivers mentioned above remained after the glaciations due to high-elevation mountain ranges such as the Sierra Madre Oriental, the Rocky Mountains, and the Sierra Madre Occidental, leading to the vicariant distribution of beavers (López-Wilchis 1998).

Beavers in the Río Bravo basin are found on both sides of the U.S. A.-México border in the states of Chihuahua and Tamaulipas, in the protected areas Área de Protección de Flora y Fauna Cañón de Santa Elena (Santa Elena Canyon Protected Area for Flora and Fauna) and Big Bend National Park (Carreón-Hernández 2014). Beavers have also been recorded occasionally in other areas of Baja California, Chihuahua, Coahuila, Nuevo León, and Tamaulipas since 1965 (Leopold 1959; Vásquez-Farías 1996; López-Wilchis 1998; Mellink and Luévano 1998; Espinoza-Martínez et al. 2016). A specimen collected by Goldman in 1902 is the last known record of a beaver from the Conchos River in central Chihuahua (Bailey 1905; Anderson 1972). Evidence of beavers in gnawed tree trunks, tracks, and dens at Mezquite, a locality near the Pegüis Canyon, on the Conchos River closer to Ojinaga was observed by Anderson (1972). No new records of beavers beyond those mentioned by Anderson (1972), or the ones found by López-Wilchis (1998) near Ojinaga on the Río Grande (Río Bravo), and of those mentioned by López-González and García-Méndoza (2012). Years later, beaver tracks were mentioned by interviewed people in the Pegüis Canyon by Jiménez-González et al. (2004). Here we report on new records that confirm the presence of beavers in the Conchos River, specifically in the Pegüis Canyon, and discuss the current distribution and conservation status of beavers in the state of Chihuahua, México.

A field expedition to survey the Conchos River for river otters and beavers was conducted on October 24-27, 2019. We were searching for tracks, footprints, gnawed bark, felled trees and dens to confirm beaver presence; observations of tracks, footprints, gnawed bark and dens were identified according to Murie and Elbroch (2005) and identification of trees were done based on photographs and interviewed local people and their confirmed presence mentioned on Jiménez-González et al. (2004). We used canoes to survey both banks of the Conchos River in the Pegüis Canyon area. We canoed for four kilometers to a point located one $\mathrm{km}$ beyond the Mirador resting area on the MX 16 (Chihuahua - Ojinaga) highway. Beaver locations were registered with a GPS, readings taken at each location were corrected $a$ posteriori to account for the poor reception inside the canyon (Figure 1). Other reaches of the Conchos and its affluents were surveyed for the presence of beavers in 2018 and 2019 by walking $5 \mathrm{~km}$ along both riverbanks searching for signs of beaver presence. Surveyed rivers in Central Chihuahua were: four sites at Conchos River, two sites at San Pedro River, two sites at Balleza River, two sites at Santa Isabel River and one site at Satevó River. In Durango, one site at Florido River (Table 1).

We found signs of beaver presence (e. g., footprints, tracks and gnawed bark and tree trunks) in several muddy or sandy beaches along the riverbanks. We also surveyed a small section of the northern end of the Pegüis Canyon, where we found the gnawed bark of a pirul tree (Schinus molle) on the western bank of the river (Figure 2). Pirul trees were introduced to this part of Ojinaga many years ago and were planted on the site to provide shade for an eco-tour-

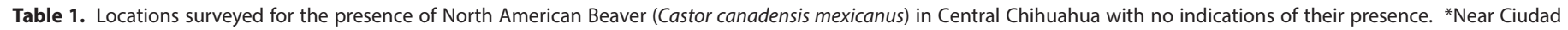
Camargo (locality from Anderson 1972). ${ }^{* *}$ In the state of Durango.

\begin{tabular}{|c|c|c|c|c|c|}
\hline ID Number & River & Locality & Latitude (N) & Longitude (W) & Elevation (m) \\
\hline 1 & Conchos & Valle de Zaragoza & $27^{\circ} 24.549^{\prime}$ & $105^{\circ} 50.830^{\prime}$ & 1,343 \\
\hline 2 & Conchos & $\mathrm{N}$ of Valle de Zaragoza & $27^{\circ} 27.610^{\prime}$ & $105^{\circ} 49.237^{\prime}$ & 1,333 \\
\hline 3 & Conchos & Below La Boquilla reservoir* & $27^{\circ} 32.911^{\prime}$ & $105^{\circ} 24.697^{\prime}$ & 1,260 \\
\hline 4 & Conchos & El Granero reservoir & $27^{\circ} 58.403^{\prime}$ & $105^{\circ} 17.902^{\prime}$ & 1,042 \\
\hline 5 & San Pedro & Near Santa María de Cuevas & $27^{\circ} 51.578^{\prime}$ & $106^{\circ} 20.419^{\prime}$ & 1,463 \\
\hline 6 & San Pedro & Below Las Vírgenes reservoir & $28^{\circ} 09.760^{\prime}$ & $105^{\circ} 37.274^{\prime}$ & 1,199 \\
\hline 7 & Balleza & La Cruz & $26^{\circ} 54.660^{\prime}$ & $106^{\circ} 19.841^{\prime}$ & 1,584 \\
\hline 8 & Balleza & Balleza & $26^{\circ} 58.485^{\prime}$ & $106^{\circ} 20.773^{\prime}$ & 1,556 \\
\hline 9 & Florido & Near Villa de Ocampo** & $26^{\circ} 26.635^{\prime}$ & $105^{\circ} 33.107^{\prime}$ & 1,738 \\
\hline 10 & Santa Isabel & Charco Largo & $28^{\circ} 17.918^{\prime}$ & $106^{\circ} 16.637^{\prime}$ & 1,538 \\
\hline 11 & Santa Isabel & Near Ejido San Miguel & $28^{\circ} 11.142^{\prime}$ & $106^{\circ} 13.754^{\prime}$ & 1,478 \\
\hline 12 & Satevó & Near bridge of $M \times 24$ & $27^{\circ} 57.958^{\prime}$ & $106^{\circ} 08.521^{\prime}$ & 1,391 \\
\hline
\end{tabular}




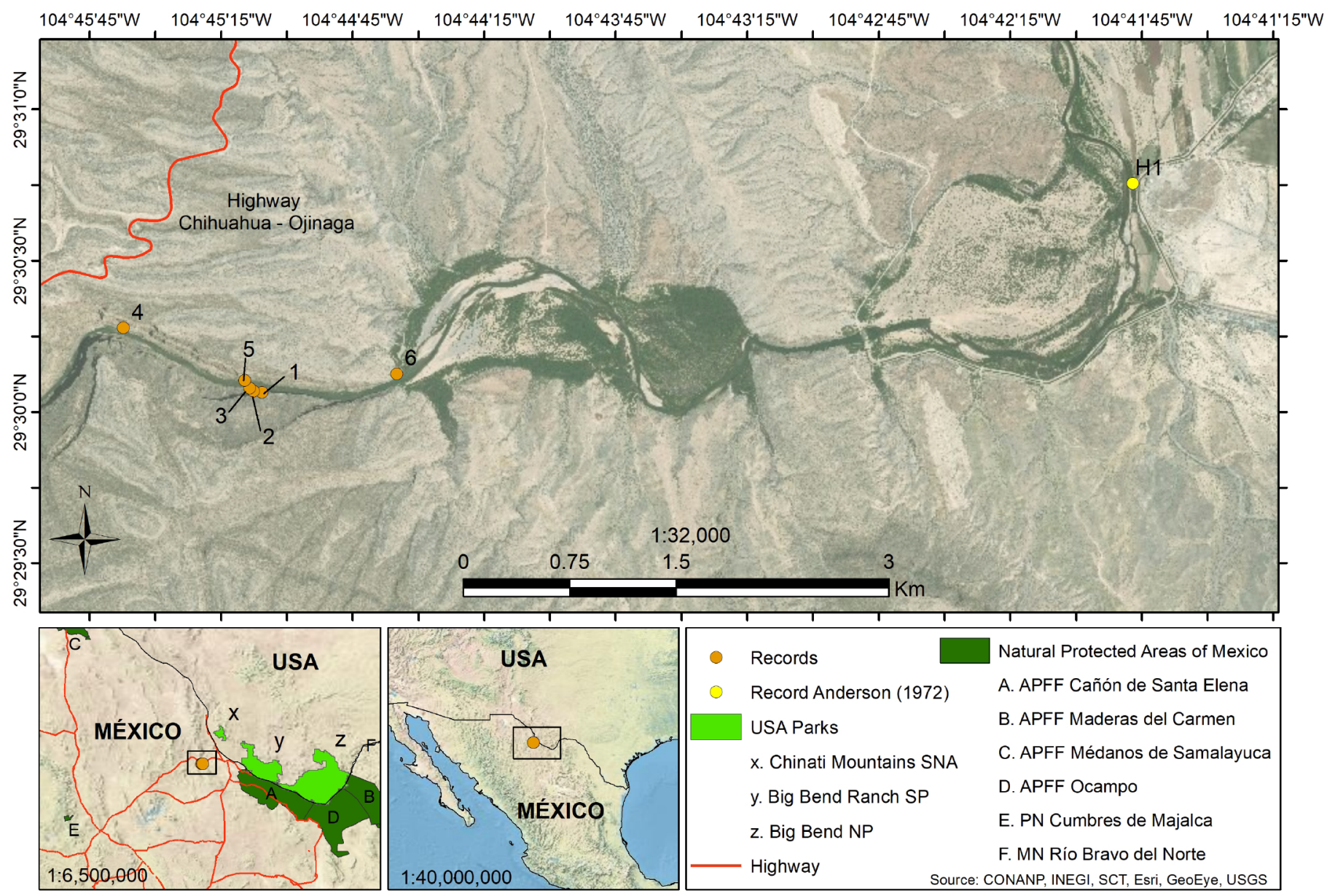

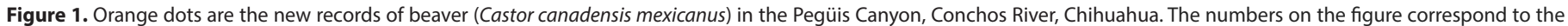

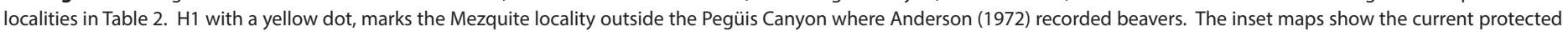
areas in México and the United States of America, showing the lack of protection for this species (left), and the general area in México where these new records were noted (right).

ism spot. Beaver activity was evident in this zone where the bark and small branches of other five pirul trees had been gnawed and taken away, causing the death of some of them. In addition, small branches of mesquite trees (Prosopis glandulosa) had also been cut down and carried to the river by beavers (Table 2 ).

The beaver habitat in the area was found to be wellpreserved. The river banks were covered by dense tree vegetation dominated by mesquite (Prosopis glandulosa), palo verde (Parkinsonia microphylla), huizache (Acacia sp.), willows (Salix sp.), cottonwood (Populus sp.), saltcedar (Tamarix ramossissima), and giant reed (Arundo donax), together with tall shrubs such as jarilla (Baccharis neglecta), and a lower layer including thorny shrubs such as gatuño (Acacia greggii) and several grass and herb species. Inside the Pegüis Canyon, the vegetation of sandy banks consisted mostly of thickets of giant reed and jarilla; in contrast, mesquite, willow, and cottonwood were common on more rocky substrates. Vegetation beyond the riverbanks consisted mainly of lechuguilla (Agave lechugilla), creosote bush (Larrea tridentata), ocotillo (Fouqueira splendens), sotol (Dasilyrion sp.), prickly pear (Opuntia spp.), and other cacti and yucca (Yucca spp.).

The beaver habitat at the Pegüis Canyon is a long stretch of almost vertical, high rocky walls reaching 350-400 m
(Figure 2); it is the boundary between the Sierra del Pegüis and Sierra de Matasaguas mountain ranges, the canyon is formed of Upper Cretaceous limestone (Flotte et al. 2008). The Conchos River meanders inside the canyon along 17 kilometers from its source at El Álamo to its mouth near the Mezquite locality. The river shows broad shallow reaches with sandy gravel bottom at the lower parts of the canyon, and narrow reaches with deep pools at the uppermost parts. A rocky barrier formed of large boulders that have fallen from the sheer walls occurs in the middle segment of the canyon; this section of the river is difficult to navigate due to the numerous rapids and flooding events in the rainy season (Jiménez-González et al. 2004). Faulting is evident in the extensive longitudinal cuts at various angles that form terraces at different inclination angles and heights. Riverbanks are made up of boulders, fallen rock debris, and sand/gravel or mud/sand beaches covered by vegetation.

Regarding biodiversity in the beaver's riparian habitat, that add importance to the canyon, we observed other fauna, such as a gray fox (Urocyon cinereoargenteus) in a crevice in the canyon wall on the western riverbank; several tracks of Nearctic otter (Lontra canadensis) on both sides of the river on sandy areas with patches of grass, giant reed, and jarilla; and tracks of raccoon (Procyon lotor) on muddy 


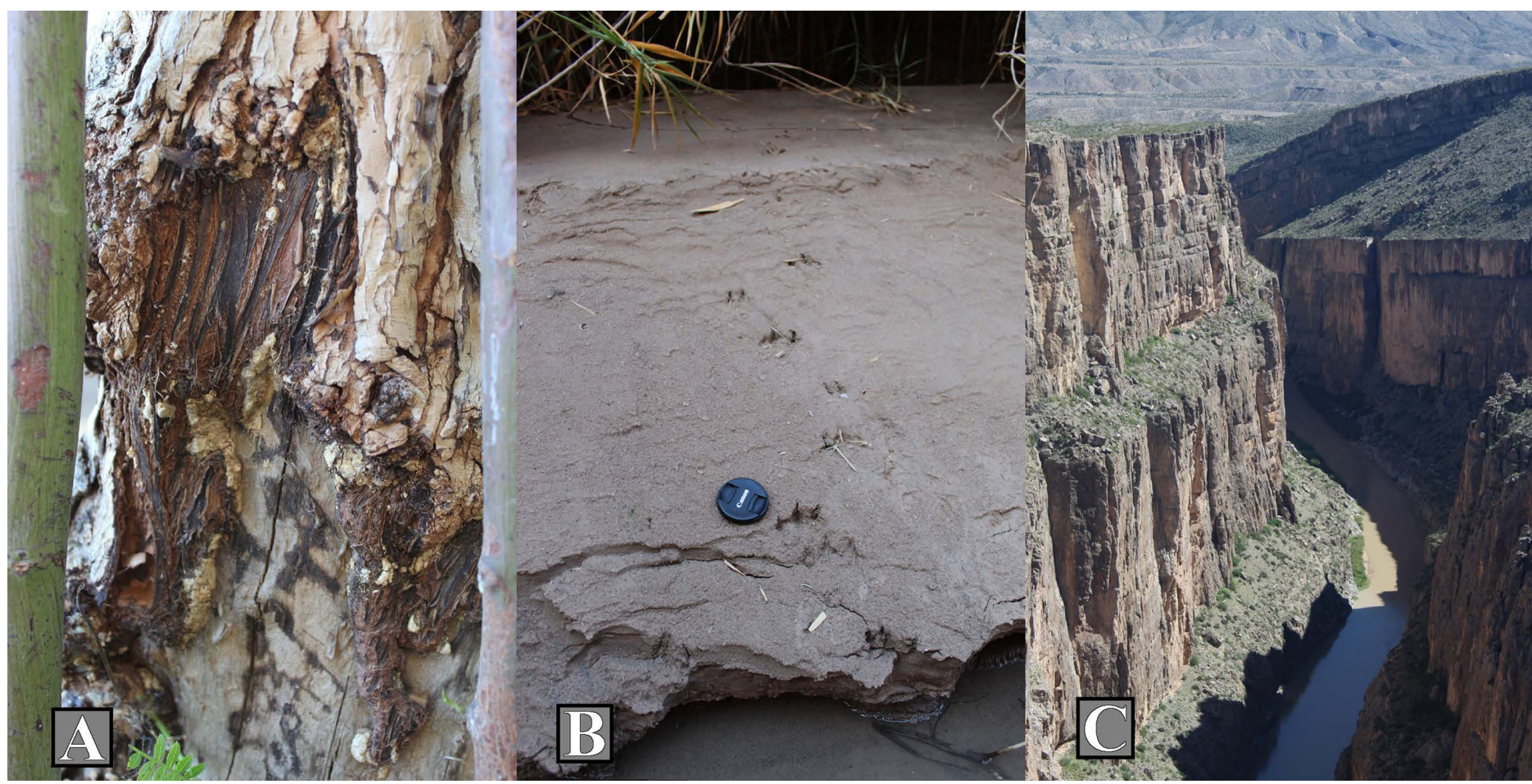

Figure 2. A) Trunk of a pirul tree (Schinus molle) gnawed by North American beavers (Castor canadensis) at the mouth of the Pegüis Canyon (Photo: I. Barba-Acuña). B) Beaver tracks on a sandy riverbank in the beaver's habitat. C). View of the Pegüis Canyon, the habitat of beavers at this portion of Conchos River (Photos: J. P. Gallo-Reynoso).

and sandy substrates. We also identified nests of cliff swallow (Petrochelidon pyrrhonota) on some cliffs, and several individuals of Gray heron (Ardea herodias), killdeer (Charadrius vociferus), and black phoebe (Sayornis nigricans), as well as individuals and nests of Comanche paper wasps (Polistes comanchus). Some fishes were observed but were unidentifiable because of the turbid water.

The middle portion of the Conchos River at Ciudad Camargo has not been thoroughly surveyed for the presence of beavers to confirm or dismiss previous records. We surveyed the banks of the Conchos River at Valle de Zaragoza, below the La Boquilla reservoir near Ciudad Camargo (at the locality referred to by Anderson 1972) or at El Granero reservoir. Surveys were also made at several affluents of the Conchos River; below Las Vírgenes reservoir on the San Pedro River, at Balleza River, at Río Florido, at Santa Isabel River and at Satevó River. We found no signs of gnawed or downed tree trunks, dens, or beaver tracks in any of these sites, although the local inhabitants (fishermen, ranchers, and farmworkers) of Conchos River know of their presence of or did observe beavers several decades ago before the reservoirs were built.

Our observations confirm the presence of the North American beaver in the Pegüis Canyon and add new records to the list of the fauna of this area, whose biodiversity, historic, and scenic values should be preserved (Jiménez-González et al. 2004). The beaver population in this area is probably derived from the beavers found at Río Grande near Ojinaga or from the Natural Protected Area of Cañón de Santa Elena further south. Our findings are significant and suggest that the area is fairly well-preserved and important for the distribution of beavers in northern México, which enhances the need for conservation of this section of the Conchos River as an important corridor for the species. However, this area on the Conchos River is currently not protected to safeguard either beaver populations or the biodiversity of the Pegüis Canyon (Figure 1).

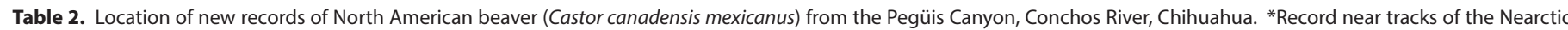
otter (Lontra canadensis). H1: record at the Conchos River from Anderson (1972). Numbers in the table correspond to the map on Figure 1.

\begin{tabular}{|c|c|c|c|c|}
\hline ID Number & Record type & Latitude (N) & Longitude (W) & Elevation (m) \\
\hline 1 & Tracks on a sandy riverbank & $29^{\circ} 30.041^{\prime}$ & $104^{\circ} 45.116^{\prime}$ & 938 \\
\hline 2 & Tracks on a sandy riverbank & $29^{\circ} 30.068^{\prime}$ & $104^{\circ} 45.127^{\prime}$ & 943 \\
\hline 3 & $\begin{array}{l}\text { Tracks on a sandy riverbank, den, on an area dominated by giant reed } \\
\text { (Arundo donax) }\end{array}$ & $29^{\circ} 30.078^{\prime}$ & $104^{\circ} 45.142^{\prime}$ & 944 \\
\hline 4 & Tracks on a muddy riverbank & $29^{\circ} 30.338^{\prime}$ & $104^{\circ} 45.596^{\prime}$ & 985 \\
\hline 5 & Tracks on a sandy riverbank* & $29^{\circ} 30.104^{\prime}$ & $104^{\circ} 45.160^{\prime}$ & 930 \\
\hline 6 & Gnawed trunk of a pirul tree (Schinus molle) & $29^{\circ} 30.126^{\prime}$ & $104^{\circ} 44.583^{\prime}$ & 836 \\
\hline $\mathrm{H} 1$ & Approximate location of the "Mezquite" record from Anderson (1972) & $29^{\circ} 30.756^{\prime}$ & $104^{\circ} 41.784^{\prime}$ & 819 \\
\hline
\end{tabular}


It is worth noting that, before entering the Pegüis Canyon, the waters of the Conchos River flow through vast agricultural and urban areas in the central part of Chihuahua State, where numerous dams divert water to irrigation channels and the river receives urban and agricultural wastewater. Such conditions warrant the close monitoring of water quality and beaver occupation in the area to ensure the long-term survival of beavers which are listed as endangered by Mexican Official Norm NOM-059-SEMARNAT-2010 (SEMARNAT 2010), and to preserve the biodiversity and scenic values of the Pegüis Canyon.

This note is dedicated to the memory of Dr. Sydney Anderson (1927-2018) that conducted extensive fieldwork in Chihuahua in 1952, and from 1956-1960. He collected and prepared over 1,000 mammals from Chihuahua and produced an extensive reference of the mammals found in the state (Gardner et al. 2020).

\section{Acknowledgements}

We are indebted to Tarahumara Sustentable - WWF for partially funding our work through the grant GK-26. We thank two anonymous reviewers which improved the outcome of our study. María Elena Sánchez-Salazar edited the English manuscript.

\section{Literature cited}

Anderson, S. 1972. Mammals of Chihuahua, México, taxonomy and distribution. Bulletin of the American Museum of Natural History 148:149-410.

Balley, V. 1905. Biological survey of Texas. North American Fauna 25. U.S. Government Printing Office. Washington, D. C., U.S.A.

CaIRE, W. 2019. The Distribution of the Land Mammals of Sonora, Mexico. Journal of the Arizona-Nevada Academy of Science 48:40-219.

Carreón-Hernández, E. 2014. Mamíferos. Ecosistemas Acuáticos. Pp. 511-513 in La Biodiversidad en Chihuahua. Estudio de Estado (Barajas, N., A. Cruz-Aragón, J. Valero-Padilla, and J. C. Treviño Fernández, coords.). Comisión Nacional para el Conocimiento y Uso de la Biodiversidad. México City, México.

Espinoza-Martínez, D. V., C. A. Ríos-Muñoz, N. González-Ruíz, J. Ramírez-Pulido, L. León-Paniagua, and J. Arroyo-Cabrales. 2016. Mamíferos de Coahuila. Revista Mexicana de Mastozoología Nueva época 6:1-28.

Flotte, N., J. Martínez-Reyes, C. Ragnin, X. Le Pichon, L. Husson, AND M. TARDY. 2008. The Rio Bravo fault, a major late Oligocene left-lateral shear zone. Bulletin de la Societé Géologique de France 179:147-160.

Gallo-Reynoso, J. P., G. Suarez-Gracida, H. Cabrera-Santiago, E. Coria-Galindo, J. Egido-Villarreal, and L. C. Ortiz. 2002. Status of beavers (Castor canadensis frondator) in Rio Bavispe, Sonora, México. Southwestern Naturalist 47:501-504.

Gardner, S. C., R. M. Timm, N. Olds, and H. H. Genoways. 2020. Obituary. Sydney Anderson (1927-2018). Journal of Mammalogy 101:900-915.

Jiménez-González, G., C. M. Valencia-Castro, and A. CarrilloReyes. 2004. Factibilidad de establecer un Área Natural Pro- tegida en el "Cañón y Sierra del Peguis" (Bajo Conchos). Final report. Biodesert, A. C., in collaboration with Environmental Defense. 40 p. Torreón, Coahuila. Available at jpgallo@ciad.mx LEopold, A. S. 1959. Wildlife of Mexico: the game birds and mammals. University of California Press. Berkeley, U.S.A.

López-González, C., And D. F. García-Mendoza. 2012. A checklist of the mammals (Mammalia) of Chihuahua, Mexico. Check List 8:1122-1133.

López-WiLchis, R. 1998. Base de datos de mamíferos de México depositados en colecciones de Estados Unidos y Canadá. Universidad Autónoma Metropolitana-Iztapalapa. Final report SNIB-CONABIO project No. P130. México City, México. Available at jpgallo@ciad.mx

Mearns, E. A. 1907. Mammals of the Mexican boundary of the United States: a descriptive catalogue of the species of mammals occurring in that region; with a general summary of the natural history, and a list of trees. United States National Museum Bulletin 56:1-530.

Meluink, E., ANd J. Luévano. 1998. Status of beavers (Castor canadensis) in Valle de Mexicali, México. Bulletin of the Southern California Academy of Sciences 97:115-120.

Murie, O. J., AND M. Elbroch. 2005. A field guide to animal tracks. Houghton Mifflin Company. New York, U.S.A.

Olivares-Rivera, S. 2018. Estado actual de la población del castor (Castor canadensis) en la cuenca alta del Río San Pedro, Sonora. Bachelors Thesis. Universidad de Sonora. Hermosillo, Sonora, México.

Pelz-Serrano, K., E. Ponce-Guevara, and C. A. López-González. 2005. Habitat and conservation status of the beaver in the Sierra San Luis Sonora, México. USDA Forest Service Proceedings RMRS-P. 36:429-433.

Rybczynski, N., E. M. Ross, J. X. Samuels, and W. W. Korth. 2010. Re-Evaluation of Sinocastor (Rodentia: Castoridae) with Implications on the Origin of Modern Beavers. Plos One 5:e13990.

Secretaria de Medio Ambiente y Recursos Naturales (SEMARNAT). 2010. Norma Oficial Mexicana NOM-059-SEMARNAT-2010, Protección ambiental-Especies nativas de México de flora y fauna silvestres-Categorías de riesgo y especificaciones para su inclusión, exclusión o cambio-Lista de especies en riesgo. Diario Oficial de la Federación 2454:1-77.

VÁsquez-Farías, E. P. 1996. Factores del hábitat que determinan la presencia del castor (Castor canadensis mexicanus), en el norte de Nuevo León, México. Master's Thesis. Universidad Autónoma de Nuevo León. Monterrey, México.

Villa-Ramírez, B. 1954. Distribución de los castores en México. Anales del Instituto de Biología. Universidad Nacional Autónoma de México 25:443-450.

Associated editor: Tamara Rioja-Paradela

Submitted: October 30, 2020; Reviewed: December 8, 2020.

Accepted:December 9, 2020; Published on line: December 17, 2020. 